\title{
Emissions of polyciclic aromatic hydrocarbons and polyciclic carbonyl biphenils from electric arc furnaces ${ }^{(\cdot)}$
}

\author{
J.F.P. Gomes ${ }^{*}$ **
}

\begin{abstract}
This paper describes work done in order to determine the emissions of highly toxic organic micropollutants from electric arc furnaces used in the production of carbon steel from scrap. The study will be allowing to derive relationships between the levels of airborne micropollutants and the operational parameters of the production process so that an abatement of pollution could be achieved. By using the European standard method CEN 1948 for dioxin like compounds sampling and measurement, it was possible to determine the characteristic fingerprint of micropollutants such as polyciclic aromatic hydrocarbons (PAHs) and polycyclic carbonyl biphenils (PCBs) emitted by this particular stationary source.
\end{abstract}

\section{Emisiones de hidrocarburos aromáticos policíclicos y bifenilos carboxilados policíclicos en hornos eléctricos de arco}

\begin{abstract}
Resumen
Este artículo contiene resultados del trabajo ejecutado para estudiar la determinación de las emisiones de los micropolutantes orgánicos muy tóxicos que se emiten por los hornos eléctricos de arco utilizados en la producción de acero. Este estudio inicial va a permitir relacionar las concentraciones de polutantes emitidos a la atmósfera con las condiciones de operación del horno eléctrico de arco. Utilizando el método normalizado CEN 1948 para captación y análisis de muestras de compuestos análogos a las dioxinas ha sido posible determinar el perfil característico de los micropolutantes tales como PAHs y PCBs emitidos por esta fuente.
\end{abstract}

Palabras clave

PAHs. PCBs. Industria del acero. Horno eléctrico de arco.

\section{INTRODUCTION}

In a previous paper ${ }^{[1]}$, the author described a study on the evaluation and assessment of dioxin (PCDDs) and dibenzofurans (PCDFs) atmospheric emissions from electric arc furnace (EAF) steel making process. In particular, when ferrous scrap results from the automobile industry it frequently includes plastics such as polyvinylchloride, thus resulting in atmospheric emissions of dioxin like compounds. Apart from plastics other organic compounds that could act as PCDDs and PCDFs precursors can be found in scrap used as raw material for steel production by this process.
It is well known ${ }^{[2]}$ that PCBs, unlike other highly toxic compounds such as PCDDs and PCDFs have been produced industrially, bearing in mind their specific physico-chemical properties that could be used in several applications. In fact, they are almost non-combustible, have very low vapour pressures at room temperature, are non-volatile and non-soluble, have considerable thermal and chemical stability, resistant both to acid and alkali substances. Therefore, they have been used as dielectric fluids used in electrical transformers and condensers; as adhesives, paints, hydraulic lubricants, etc. Nevertheless, its toxicity has been widely demonstrated, which resulted in the restriction of $\mathrm{PCB}$ for use in several applications. Both PCBs and PAHs have been

(·) Trabajo recibido el día 8 de febrero de 2007 y aceptado en su forma final el día 12 de julio de 2007.

* Chemical Engineering Department, IST - Instituto Superior Técnico, Torre Sul, Av. Rovisco Pais, 1, $1049-001$ Lisboa, Portugal

** Chemical Engineering Department, ISEL - Instituto Superior de Engenharia de Lisboa, R. Conselheiro Emídio Navarro, 1, 1949-014

Lisboa, Portugal Fax: 351.21.3850991 Email: jgomes@deq.isel.ipl.pt. 
reported as emitted from the steel and metallurgic industries, namely when scrap is melted again in recycling processes, such as steel making from scrap via the EAF process ${ }^{[3 \text { and } 4]}$.

\section{EXPERIMENTAL}

In order to attain the project objectives, a set of sampling campaigns, followed by laboratorial analysis, have been undertaken at the stacks of the dedusting units of a Portuguese EAF located in Northern Portugal. The specific characteristics of the plant, as well as of the installed equipment were described previously by the author ${ }^{[1]}$.

The sampling technique was based on the European Standard method EN1948 [5-7], which specifically concerns dioxin and dibenzofuran sampling and analysis. However, certain modifications were introduced in order to isokinetically sample $\mathrm{PAHs}$ and $\mathrm{PCBs}$. The analytical determinations were performed in a HRGC/HRMS, VG-AutoSpec using capillary columns DB5. PAHs analysis included the determinations of 16 congeners, defined according USEPA, using deuterated extracts ranging from $\mathrm{D}^{8}$ to $\mathrm{D}^{14}$, as follows:
Naphthalene,
Acenaftalene,
Acenaftene,
Fluorene,
Fenantrene,
Anthracene,
Fluorantene,
Pirene,
Benzo(a)anthracene,
Crisene,
Benzo(b)fluorantene,
Benzo(k)fluorantene,
Benzo(a)pirene,
Indene(1,2,3)-cd-pirene,
Benzo(ghi)perilene,
Dibenzo(ah)anthracene

Regarding PCBs, the analysis covered the isomers $28,52,101,138,153,180$ and total homologue, using internal standards marked with ${ }^{13} \mathrm{C}$. For the utilized sampling volumes, the detection limit both for PAHs and PCBs was determined at $0.01 \mathrm{mg} / \mathrm{m}^{3}$. The basic sampling procedure, using a cooled probe, was described previously ${ }^{[1]}$. The sampling time was now considerably reduced, from the sampling time necessary for PCDDs/PCDFs, to about an hour.

Particulate matter was collected on a filter and the gaseous phase was collected by condensation on an adsorbent agent. After sample recovery, the sampling train was decontaminated using water and acetone. Filters and adsorbents are mixed together for extraction with an organic solvent by soxhlet and then concentrated in a rotovapour device. It is necessary to remove any interferents from the final extract before performing the chromatographic analysis by HRGC/HRMS. The determinations are made by adding internal and external deuterated standards as follows:

$\begin{array}{ll}\text { Naphthalene } & \mathrm{D}_{8} \\ \text { Acenaftalene } & \mathrm{D}_{10} \\ \text { Fenantrene } & \mathrm{D}_{10} \\ \text { Pirene } & \mathrm{D}_{10} \\ \text { Benzo(k)fluorantene } & \mathrm{D}_{12} \\ \text { Benzo(a)pirene } & \mathrm{D}_{12} \\ \text { Dibenzo(ah)anthracene } & \mathrm{D}_{14} \\ \text { Benzo(ghi)perilene } & \mathrm{D}_{12}\end{array}$

The same sample was used for determination of PCB 28, 52, 101, 138, 153, 180 and total homologue. This later determination was made using the following internal standards:

$\begin{array}{ll}\text { 2,4,4'-Tri-PCB (PCB-28) } & { }^{13} \mathrm{C}-\mathrm{UL} \\ \text { 2,2', } 5,5^{\prime} \text {-Tetra-PCB (PCB-52) } & { }^{13} \mathrm{C}-\mathrm{UL} \\ \text { 2,2',4,5,5'-Penta-PCB (PCB-101) } & { }^{13} \mathrm{C}-\mathrm{UL} \\ \text { 2,2',3,4,4',5'-Hexa-PCB (PCB-138) } & { }^{13} \mathrm{C}-\mathrm{UL} \\ \text { 2,2', } 4,4^{\prime}, 5,5^{\prime} \text { '-Hexa-PCB (PCB-153) } & { }^{13} \mathrm{C}-\mathrm{UL} \\ \text { 2,2',3,4,4',5,5'-Hepta-PCB (PCB-180) } & { }^{13} \mathrm{C}-\mathrm{UL}\end{array}$

After the addition of standards, samples were extracted with nanograde specific solvents. The procedure for interferent removal, already described for PAHs, was also used here prior to the chromatographic determination

\section{RESULTS AND DISCUSSION}

Within the scope of European standards there is no standardized method for the determination of the uncertainty of measurement that covers both sampling and the analytical procedure as well as the uncertainty related with the conditions of the sampling site in special. For this reason the single results are not supplied with information of uncertainty. Our experience shows that, in general, uncertainties in the range of $10 \%$ to $20 \%$ for the components listed in the above tables. For values near the detection limit the uncertainties are higher. Based on the measurements made, figure 1 shows the existence of individual species of PAHs, where a prominence of naphthalene, acenaftalene, fenantrene and fluorene could be noticed. Other species such as fluorantene, pirene, acenaftene and crisene were also found in lower amounts. As a whole, the existence of 12 of the 16 searched species of PAHs was verified, as benzo(a)pirene,indene(1,2,3)-cd-pirene, benzo(ghi)perilene and dibenzo(a,h)anthracene were not detected.

Carefully observing this figure, with a zoom from anthracene on, the existence of a coherent profile is 

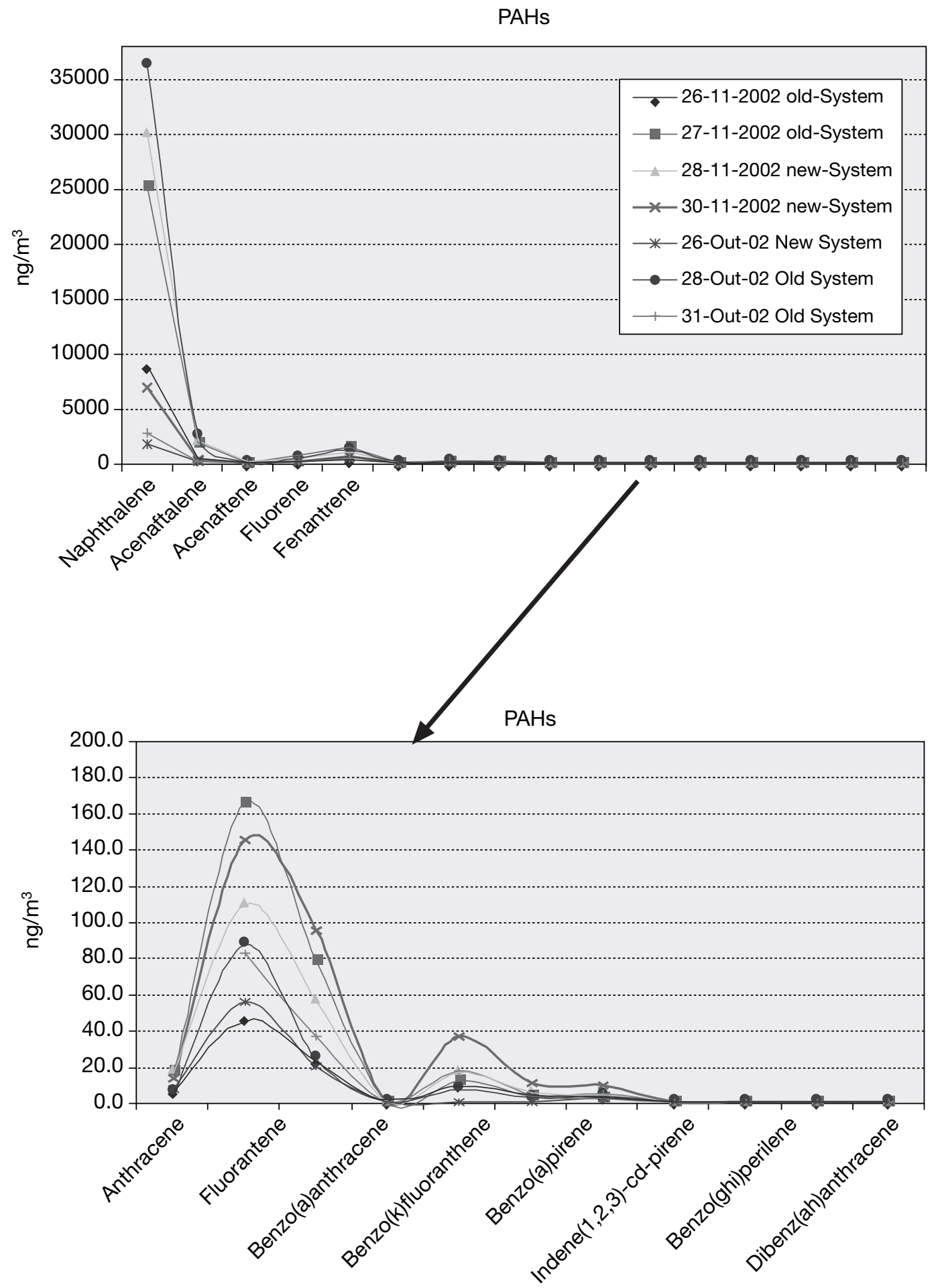

Figure 1. Profile of PAHs obtained in 7 measurements.

Figura 1. Perfil de concentraciones de PAH obtenido en 7 medidas.

also verified, and this is the actual "fingerprint" of this process in terms of PAHs emissions. In fact, it can be noted that this profile is always observed during the operation of this EAF system and is non-dependant of the gas flow rate neither of the
EAF actual processing capacity. The observed variations can possibly be explained by different production regimes, using different loads for the furnace, which were observed during sampling operations. Table I presents the main physical and 
EMISSIONS OF POLYCICLIC AROMATIC HYDROCARBONS AND POLYCICLIC CARBONYL BIPHENILS FROM ELECTRIC ARC FURNACES EMISIONES DE HIDROCARBUROS AROMÁTICOS POLICÍCLICOS Y BIFENILOS CARBOXILADOS POLICÍCLICOS EN HORNOS ELÉCTRICOS DE ARCO

Table I. Physico-chemical properties of PAHs ${ }^{[2]}$

Tabla I. Propiedades físico-químicas de los $\mathrm{PAH}^{[2]}$

\begin{tabular}{lccccc}
\hline \multicolumn{1}{c}{ PAHs } & $\begin{array}{c}\mathrm{N}^{\circ} \text { of } \\
\text { rings }\end{array}$ & $\begin{array}{c}\text { Mol. } \\
\text { Weight } \\
(\mathbf{g} / \mathbf{m o l})\end{array}$ & $\begin{array}{c}\text { Fusion } \\
\text { point } \\
\left({ }^{\circ} \mathrm{C}\right)\end{array}$ & $\begin{array}{c}\text { Boiling } \\
\text { point } \\
\left({ }^{\circ} \mathrm{C}\right)\end{array}$ & $\begin{array}{c}\text { Chemical } \\
\text { Formula }\end{array}$ \\
\hline Naphthalene & 2 & 128 & 80.6 & 218 & $\mathrm{C}_{10} \mathrm{H}_{8}$ \\
Acenaftalene & 3 & 152 & 94 & 265 & $\mathrm{C}_{12} \mathrm{H}_{8}$ \\
Fenantrene & 3 & 178 & 99.5 & 340 & $\mathrm{C}_{14} \mathrm{H}_{10}$ \\
Fluorene & 3 & 166 & 116 & 295 & $\mathrm{C}_{13} \mathrm{H}_{10}$ \\
Acenaftene & 3 & 154 & 95 & 279 & $\mathrm{C}_{12} \mathrm{H}_{10}$ \\
Anthracene & 3 & 178 & 217 & 370 & $\mathrm{C}_{14} \mathrm{H}_{10}$ \\
Fluorantene & 4 & 202 & 110.8 & 375 & $\mathrm{C}_{16} \mathrm{H}_{10}$ \\
Pirene & 4 & 202 & 156 & 404 & $\mathrm{C}_{16} \mathrm{H}_{10}$ \\
Crisene & 4 & 228 & 255 & 448 & $\mathrm{C}_{18} \mathrm{H}_{12}$ \\
Benzo(a)anthracene & 4 & 228 & 159.8 & 437.6 & $\mathrm{C}_{18} \mathrm{H}_{12}$ \\
Benzo(a)pirene & 5 & 252 & 176 & 495 & $\mathrm{C}_{20} \mathrm{H}_{12}$ \\
Dibenzo(a,h)anthracene & 5 & 278 & 266 & 524 & $\mathrm{C}_{22} \mathrm{H}_{14}$ \\
Benzo[k]fluorantene & 5 & 252 & 215.7 & 480 & $\mathrm{C}_{20} \mathrm{H}_{12}$ \\
Benzo[b]fluorantene & 5 & 252 & 167 & 357 & $\mathrm{C}_{20} \mathrm{H}_{12}$ \\
Indeno(1,2,3)-cd-pirene & 6 & 276 & 162.5 & 536 & $\mathrm{C}_{22} \mathrm{H}_{12}$ \\
Benzo(g,h,i)perilene & 6 & 276 & 278 & 500 & $\mathrm{C}_{22} \mathrm{H}_{12}$ \\
\hline
\end{tabular}

chemical properties ${ }^{[2]}$ of the measured PAHs. It can be noticed that the species that were not found present in the stack emissions are the species with 5 and 6 benzenic rings, which have strongly adhered to dust particles and, thus are collected by bag filters, as dust capturing devices.

The results of PCBs show a decrease of concentration with the increase of chloride atoms present in the PCB compound, as shown in figure 2. The higher content compounds are the ones having lower number of chloride atoms.

Table II presents the main physico-chemical properties of the analysed PCBs ${ }^{[2]}$. The observed trend seems to be coherent with those properties: both the fusion and the boiling points increase with the number of chlorine atoms, as well as with molecular weight. On the contrary, the vapour pressure and the evaporation rate at $25^{\circ} \mathrm{C}$ decrease with the number of chlorine atoms, and this result in a decrease of concentrations observed in the emissions.

\section{CONCLUSIONS}

These studies have, so far, allowed to derive some important conclusions on the emission of gaseous micropollutants, making possible to determine the

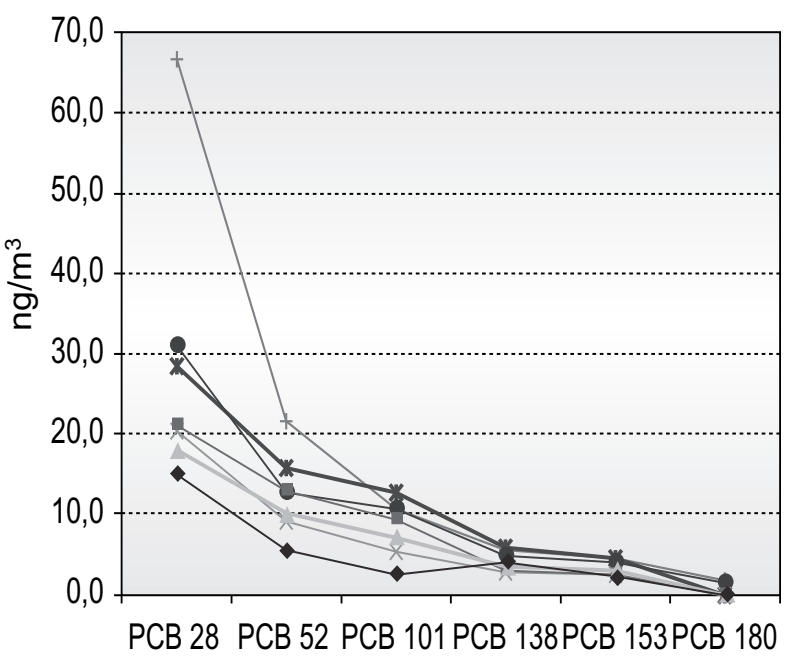

Figure 2. Profile of PCBs obtained in 7 measurements.

Figura 2. Perfil de concentraciones de PCB obtenido en medidas.

characteristic profile (also known as "fingerprint") of PCDDs/PCDFs as well as PAHs and PCBs.

In fact, in spite of some observed variability in successive sampling campaigns, it was possible to determine regular concentration profiles of the gaseous emissions of PAHs and PCBs. This is the 
Table II. Physico-chemical properties of PCBs [2]

Tabla II. Propiedades físico-químicas de los PCB [2]

\begin{tabular}{ccccccc}
\hline PCBs & $\begin{array}{c}\mathrm{N}^{\circ} \text { of } \\
\text { chlorine } \\
\text { Atoms }\end{array}$ & $\begin{array}{c}\text { Mol. } \\
\text { Weight } \\
(\mathrm{g} / \mathrm{mol})\end{array}$ & $\begin{array}{c}\text { Boiling } \\
\text { point } \\
\left({ }^{\circ} \mathrm{C}\right)\end{array}$ & $\begin{array}{c}\text { Fusion } \\
\text { point } \\
\left({ }^{\circ} \mathrm{C}\right)\end{array}$ & $\begin{array}{c}\text { Vapour } \\
\text { pressure } \\
\text { at 25 }{ }^{\circ} \mathrm{C} \\
(\mathrm{Pa})\end{array}$ & $\begin{array}{c}\text { Evaporation } \\
\text { rate } \\
\text { at 25 }{ }^{\circ} \mathrm{C} \\
\left(\mathrm{g} /\left(\mathrm{m}^{2} \mathrm{~h}\right)\right.\end{array}$ \\
\hline PCB 28 & 3 & 256 & $28-87$ & 337 & 0.054 & 0.017 \\
PCB 52 & 4 & 290 & $47-180$ & 360 & 0.012 & $4.2 \times 10^{-3}$ \\
PCB 101 & 5 & 324 & $76.5-124$ & 381 & $2.6 \times 10^{-3}$ & $1.0 \times 10^{-3}$ \\
PCB 138 & 6 & 358 & $77-150$ & 400 & $5.8 \times 10^{-4}$ & $2.5 \times 10^{-4}$ \\
PCB 153 & 6 & 358 & $77-150$ & 400 & $5.8 \times 10^{-4}$ & $2.5 \times 10^{-4}$ \\
PCB 180 & 7 & 391 & $122.4-149$ & 417 & $1.3 \times 10^{-4}$ & $6.2 \times 10^{-5}$ \\
\hline
\end{tabular}

basic information that will allow, further on, to derive further conclusions on the mechanisms of formation/destruction of these species and, at a further stage, to define operational strategies to perform the abatement of these emissions.

It should be noted that the observed existence of PAH and PCB species, which are PCDDs/PCDFs precursors, could easily result in the formation of PCDDs/PCDFs congeners by the means of heterogeneous reactions, on the surface of particles and dust that occur at temperatures higher than $300^{\circ} \mathrm{C}^{[8]}$.

\section{Ackwoledgments}

Financial support by the European Commission, through Contract NNo 7210-PR-200 is gratefully acknowledged.

\section{REFERENCES}

[1] S.L. Figueira AND J.F.P. Gomes, Rev. Metal. Madrid 41 (2005) 164-168.

[2] M.D. ERICKSON, Analytical Chemistry of PCBs, Lewis Publishers, New York, USA, 1997.

[3] D.R. ANDERSON AND R. Fisher, Chemosphere 46 (2002) 371-381.

[4] A. BueKEns, L. Stieglitz, K. Hell, H. HuANG, AND P. SEGERS, Chemosphere 42 (2001) 729-735.

[5] EuRopean Standard: CEN/EN 1948, Part 1, 1996.

[6] EuROPEAN Standard: CEN/EN 1948, Part 2, 1996.

[7] European StANDARD: CEN/EN 1948, Part 3, 1996.

[8] T. Wang, D.R. Anderson, D. ThOMPSON, M. ClENCH, AND R. FISHER, Chemosphere 51 (2003) 585-594. 